\title{
HYPERPIGMENTATION OF SKIN
}

\section{A SIGN OF VITAMIN-B ${ }_{12}$ DEFICIENCY}

BY

\author{
S. J. BAKER, M.D. \\ Professor of Medicine
}

\author{
SATHIABAMA JOHNSON, M.B., B.S. \\ Formerly Research Assistant
}

MERCY IGNATIUS, M.B., B.S.
Research Assistant

\author{
S. K. VAISH, M.B., B.S., B.Sc., Ph.D., D.T.M.\&H. \\ M.R.C.P.Ed. \\ Reader in Medicine
}

Wellcome Research Unit, Christian Medical College Hospital, Vellore, India

Increase of melanin pigmentation in the skin is well known to occur in a variety of conditions. such as Addison's disease of the suprarenals, pregnancy, and various debilitating diseases. Pigmentation of the skin has also been described in tropical sprue (Bahr, 1915; Baker, 1957). In continuing the study of pigmentation in subjects with tropical sprue and tropical megaloblastic anaemia, we have come to recognize one type of pigmentation as being associated specifically with vitamin- $B_{12}$ deficiency. This paper describes some of these cases and the investigations undertaken to establish the aetiology of the pigmentation.

\section{Materials and Methods}

The subjects studied were all South Indians attending the Christian Medical College Hospital. All cases included in this series were studied as in-patients, the majority in a metabolic ward. There were 15 adults, one of whom was seen on three occasions, and six children. The latter six cases have been described in greater detail elsewhere (Jadhav et al., 1962).

Haematological techniques employed were those described by Dacie (1956). Serum-vitamin-B ${ }_{12}$ estimations were performed by microbiological assay using Euglena gracilis $\mathrm{Z}$ strain as the test organism (Ross et al., 1957). Urinary 17-ketogenic-steroids were estimated by the method of Gibson and Norymberski (1954). A 24-hour collection of urine was made from 8 a.m. on the first day to 8 a.m. on the second day. An intravenous infusion of 20 units of A.C.T.H.* was then given over a period of eight hours and a second collection of urine made from the beginning of the infusion for a further 24 hours.

\section{Results}

The patients affected were of differing age and sex; their haemoglobin levels varied from 2.9 to $14.3 \mathrm{~g}$./100 ml., and all except two had a megaloblastic bone-marrow (Table I).

In each case the pigmentation was deep brown or brownish black in colour. The distribution and shade of pigmentation varied from patient to patient, but in all it was most pronounced in the hands and feet, and maximally so over the fingers (Fig. 1) and toes, particularly on the dorsal aspect. Characteristically it was accentuated over the interphalangeal joints and over the terminal phalanges (Fig. 2). Usually the nail itself and the nail bed were not affected, so that the pallor of the nails contrasted with the deep brown, almost black, colour of the skin of the terminal phalanges. However, in two patients the nail beds and the nails themselves were pigmented-in one patient this was a uniform pigmentation, in the other it took the form of longitudinal streaks.

${ }^{*}$ Kindly supplied by Dr. K. G. S. Nanda, Dumex Private Ltd., Bombay.
In combination with this pigmentation of the extremities there was pigmentation of other parts of the bady, differing in different cases. In two cases the patients volunteered that they had "become dark all over"; this was supported by their friends. In five cases there was a patchy pigmentation of the palms and soles. Seven patients had irregular pigmentation of the face and pigmentation of the buccal mucous membrane. One patient had a fine spotty pigmentation of the tongue. In seven patients (five children and two adults) there was pigmentation of the medial aspects of the thighs and arms and in the axillae.

Serum-vitamin- $B_{12}$ levels were low in every case (Table I). The mean serum vitamin $B_{12}$ of the group was $49 \mu \mu \mathrm{g}$. $/ \mathrm{ml}$. Thirteen of the adults had steatorrhoea and other evidence of malabsorption syndrome. In these patients the absorption of vitmain $B_{12}$ from the intestine was deficient, and was not significantly improved by the

TABLE I.-Clinical and Haematological Data

\begin{tabular}{|c|c|c|c|c|c|c|c|}
\hline $\begin{array}{l}\text { Case } \\
\text { No. }\end{array}$ & Age & Sex & $\begin{array}{c}\text { Initial } \\
\text { Hb (g.l } \\
100 \text { mi.) }\end{array}$ & $\begin{array}{l}\text { Bone- } \\
\text { Marrow }\end{array}$ & $\begin{array}{c}\text { Serum } \\
\text { Vit. } \mathbf{B}_{12} \\
\left(\mu \mu \mathbf{g} / \mathbf{m l}^{2}\right)\end{array}$ & $\begin{array}{l}\text { Steato- } \\
\text { rrhoea }\end{array}$ & $\begin{array}{c}\text { Vit. } B_{12} \\
\text { Absorption }\end{array}$ \\
\hline 1 & 50 & $\mathbf{M}$ & $7 \cdot 3$ & $\mathrm{Me}$ & 53 & Present & Defective \\
\hline $\begin{array}{l}2 \\
3 \\
4 \\
5 \\
6 \\
7 \\
8\end{array}$ & $\begin{array}{l}38 \\
22 \\
19 \\
31 \\
37 \\
16 \\
40\end{array}$ & $\begin{array}{l}\mathbf{F} \\
\mathbf{M} \\
\mathbf{M} \\
\mathbf{M} \\
\mathbf{F} \\
\mathbf{M} \\
\mathbf{M}\end{array}$ & $\begin{array}{r}2.9 \\
4.5 \\
11.2 \\
9.8 \\
7.8 \\
4.7 \\
14.3\end{array}$ & $\begin{array}{c}\ddot{"} \\
\ddot{\#} \\
\text { Normo }\end{array}$ & $\begin{array}{l}60 \\
44 \\
90 \\
88 \\
53 \\
46 \\
38\end{array}$ & "," & "", \\
\hline 9 & 32 & $\mathbf{M}$ & $5 \cdot 1$ & $\begin{array}{c}\text { Megalo- } \\
\text { blastic }\end{array}$ & 26 & ", & $"$ \\
\hline $\begin{array}{l}10 \\
11 \\
12 \\
13\end{array}$ & $\begin{array}{l}25 \\
45 \\
34 \\
31\end{array}$ & $\begin{array}{l}\mathrm{F} \\
\mathrm{F} \\
\mathrm{M} \\
\mathrm{M}\end{array}$ & $\begin{array}{r}8 \cdot 2 \\
10 \cdot 5 \\
4 \cdot 6 \\
10 \cdot 2\end{array}$ & Normo- & $\begin{array}{l}42 \\
56 \\
65 \\
48\end{array}$ & $\begin{array}{c}\text { Absent } \\
\text { Present } \\
\text { ", }\end{array}$ & $\begin{array}{c}\text { Normal } \\
\text { Defective } \\
, "\end{array}$ \\
\hline 14 & 49 & $\mathbf{M}$ & $8 \cdot 1$ & $\begin{array}{l}\text { Megalo- } \\
\text { blastic }\end{array}$ & 58 & Absent & Normal \\
\hline $\begin{array}{l}15 \\
16 \\
17 \\
18 \\
19 \\
20 \\
21\end{array}$ & $\begin{array}{c}37 \\
10 / 12 \\
8 / 12 \\
7 / 12 \\
1 \\
9 ! 12 \\
9 / 12\end{array}$ & $\begin{array}{l}\mathbf{M} \\
\mathrm{F} \\
\mathbf{M} \\
\mathbf{M} \\
\mathbf{M} \\
\mathbf{M} \\
\mathbf{M}\end{array}$ & $\begin{array}{l}6 \cdot 2 \\
3.6 \\
4 \cdot 5 \\
8 \cdot 5 \\
7 \cdot 1 \\
7 \cdot 4 \\
7 \cdot 2\end{array}$ & $\begin{array}{l}\text { ", } \\
\text { ", }\end{array}$ & $\begin{array}{l}15 \\
29 \\
62 \\
25 \\
35 \\
56 \\
64\end{array}$ & $\begin{array}{l}\text { Present } \\
\text { Absent } \\
\overline{-} \\
\text { Absent }\end{array}$ & $\begin{array}{c}\text { Defective } \\
\text { Normal } \\
\text { ", } \\
\text { ", } \\
\text { ", }\end{array}$ \\
\hline
\end{tabular}

administration of intrinsic factor. Two patients (Cases 10 and 14) showed no evidence of a malabsorption syndrome, and had a normal capacity to absorb vitamin $B_{12}$. Both were strict vegetarians and ate little or no animal protein. The six infants were born of vitamin$\mathrm{B}_{12}$-deficient mothers, and had a deficient dietary intake of vitamin $\mathrm{B}_{12}$ and normal intestinal function.

In eight patients steroid estimations were undertaken before and after the administration of A.C.T.H. (Table II).

\section{Response to Treatment}

During the whole stay in hospital all the patients were maintained on the same diet as they were having before admission. During the investigation no specific therapy 
other than vitamin $B_{12}$ was given except in Case 13. Nine adults were treated with $100 \mu \mathrm{g}$. of vitamin $B_{12}$ by injection once a week, and the remaining five with daily injections of $1 \mu \mathrm{g}$. The six infants were treated with vitamin $B_{12}$ by injection or small amounts $(0.1$ to $0.5 \mu \mathrm{g}$.) by mouth.

TABLE II.-Urinary Ketogenic Steroid Excretion Before and After A.C.T.H. Administration

\begin{tabular}{c|c|c|c}
\hline \multirow{2}{*}{ Case No. } & Sex & \multicolumn{1}{c}{ 17-Ketogenic Steroids (mg./24 hours) } \\
\cline { 2 - 3 } & & Before A.C.T.H. & After A.C.T.H. \\
\hline 2 & F & 2.6 & 8.6 \\
3 & M & 4.4 & 14.5 \\
5 & M & 4.0 & 28.5 \\
6 & M & 7.7 & 14.9 \\
8 & M & 4.6 & 12.0 \\
10 & M & 8.1 & 11.7 \\
15 & M & 5.6 & 18.2
\end{tabular}

In every case the pigmentation disappeared with the administration of vitamin $B_{12}$. As might be expected, this occurred more rapidly in the infants than in the adults. In the infants the pigmentation frequently disappeared within three weeks. In the adults obvious change was usually present within two weeks of starting vitamin $B_{12}$ therapy, but in many cases it took from 6 to 12 weeks to restore the colour to normal.

In the two cases where there was pigmentation of the nails and nail beds a definite band between the distal pigmented areas which had formed while the patient was vitamin- $B_{12}$ deficient and the new proximal unpigmented areas could be seen growing up with the nail (Fig. 3).

In Case $130.2 \mathrm{mg}$. of folic acid was given daily by injection, but this produced no haematological or clinical response and the serum-vitamin- $\mathrm{B}_{12}$ level remained low. On giving $15 \mathrm{mg}$. of folic acid daily by injection the marrow reverted to normoblastic and a decrease in pigmentation was noted. This larger dose of folic acid produced a temporary rise in serum-vitamin- $B_{12}$ levels. The decrease in pigmentation, however, was not sustained, and it finally cleared only with the administration of vitamin $B_{12}-1 \mu \mathrm{g}$./ day by injection.

\section{Pecurrent Pigmentation}

In Case 15 the pigmentation recurred at intervals over a five-year period. The patient was first seen in 1956, when his only complaint was of increasing pigmentation of the hands, feet, and face. At this time he was found to have megaloblastic anaemia, a low serum vitamin $B_{12}$ (15 $\mu \mu \mathrm{g} . / \mathrm{ml}$.), and a defect in vitamin- $\mathrm{B}_{12}$ absorption (Table III). On treatment with vitamin $\mathbf{B}_{12}$ he had a haematological remission and the pigment disappeared. In 1957 he still had a defect of vitamin- $B_{12}$ absorption, a haemoglobin of $11 \mathrm{~g}$., a ser'sm vitamin $B_{12}$ in the TABLE III.-Case 15. Clinical and Haematological Data

\begin{tabular}{|c|c|c|c|c|c|c|}
\hline \multirow[b]{2}{*}{ Date } & \multirow{2}{*}{$\begin{array}{c}\text { Pigmen- } \\
\text { tation }\end{array}$} & \multirow{2}{*}{$\begin{array}{l}\mathrm{Hb}(\mathrm{g} . \mathrm{l} \\
100 \mathrm{ml} .)\end{array}$} & \multirow{2}{*}{$\begin{array}{c}\text { Bone- } \\
\text { marrow }\end{array}$} & \multirow{2}{*}{$\begin{array}{c}\text { Serum } \\
\text { Vit. } \mathrm{B}_{12} \\
(\mu \mu \mathrm{g} . / \\
\mathrm{ml} .)\end{array}$} & \multicolumn{2}{|c|}{$\begin{array}{l}\mu \mathrm{g} . \text { Vit. } \mathrm{B}_{12} \\
\text { Absorbed }\end{array}$} \\
\hline & & & & & Alone & $\begin{array}{l}\text { Plus } \\
\text { I.F. }\end{array}$ \\
\hline September, 1956 & $++t+$ & $6 \cdot 2$ & Megalo- & 15 & 0.05 & 0.06 \\
\hline November, 1957 & - & $11 \cdot 0$ & Normo- & 170 & 0.08 & - \\
\hline August, 1958 & $+t+$ & $7 \cdot 2$ & Megalo- & 35 & $0 \cdot 11$ & $0 \cdot 10$ \\
\hline June, 1960 & ++ & $10 \cdot 0$ & $\begin{array}{c}\text { Megalo- } \\
\text { blastic }\end{array}$ & 62 & 0.07 & $0 \cdot 11$ \\
\hline
\end{tabular}

normal range, and no hyperpigmentation. In 1958 he returned complaining of a recurrence of pigmentation. At this time he again had a megaloblastic bone-marrow, with a serum vitamin $\mathrm{B}_{12}$ of $35 \mu \mu \mathrm{g}$. $/ \mathrm{ml}$. and a defective absorption. He was again treated with vitamin $B_{12}$ by injection, when his haematological condition improved and the pigmentation disappeared. He was not seen subsequently until 1960 , when he noticed the return of pigmentation. At this time he also had a megaloblastic marrow, a low serum vitamin $B_{12}$, and a defect of vitamin- $B_{12}$ absorption. Again he responded to parenteral vitamin- $B_{12}$ therapy. He has not been seen since.

\section{Discussion}

In each of the 21 cases included in this report the characteristic pigmentation of the hands and feet was

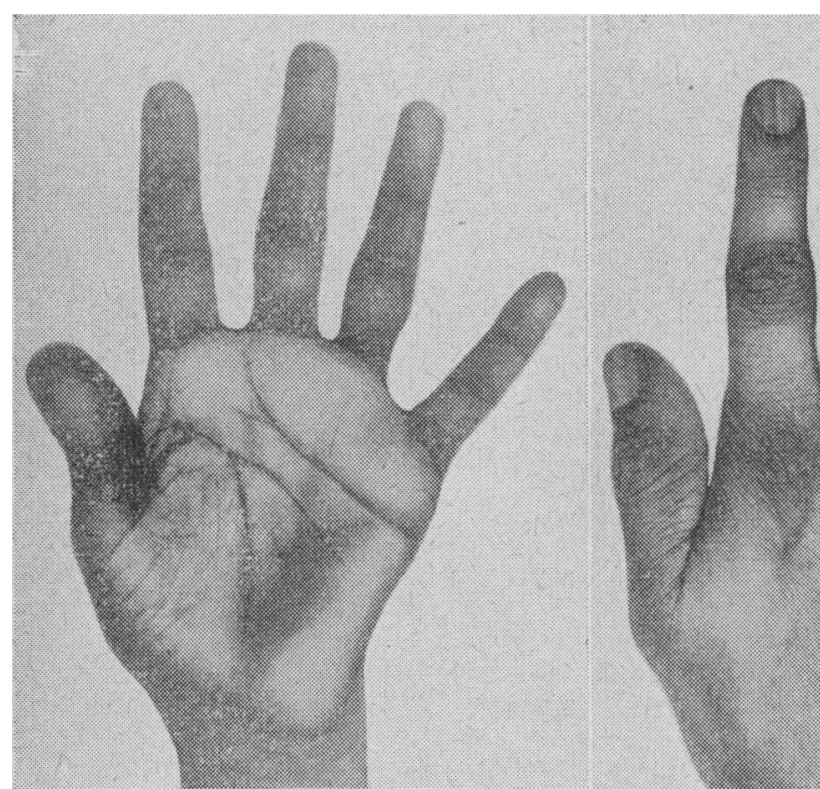

Fig. 1

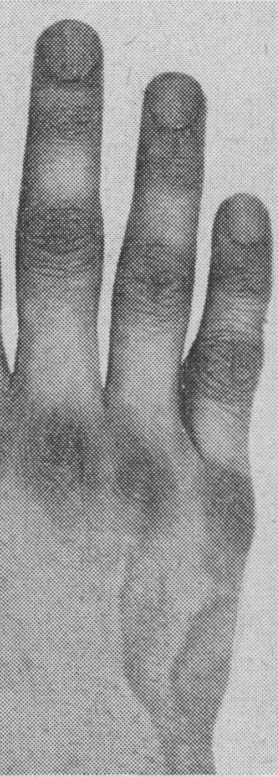

FIG. 2

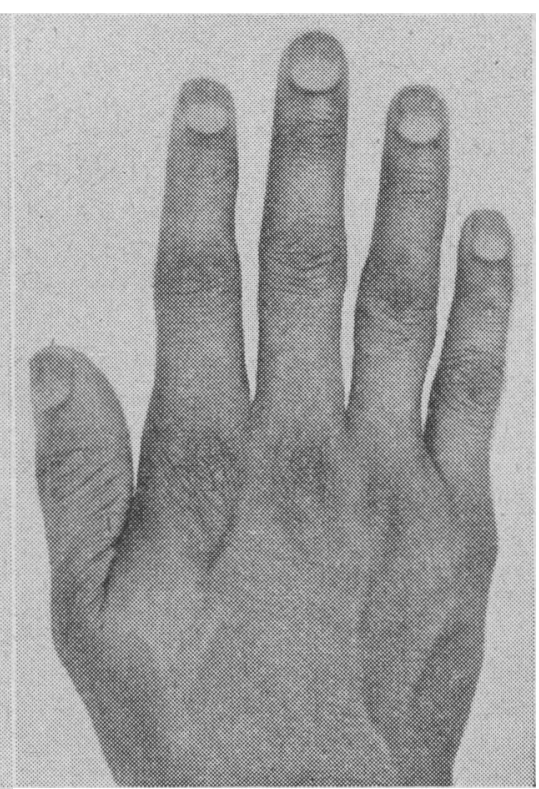

Fig. 3

Fig. 1.-Case 5. Hyperpigmentation on the palmar aspect of the fingers. There was also some increased pigmentation on the face. FIG. 2.-Case 3. Hyperpigmentation accentuated over the interphalangeal joints, the terminal phalanges, and nail beds. FIG. 3. - Case 13. Hand six weeks after starting vitamin $B_{12}$ therapy. Some pigmentation is still present on the fingers. The nails show a distal pigmented and a proximal unpigmented area with a distinct band between the two. 
associated with vitamin- $\mathrm{B}_{12}$ deficiency and disappeared with vitamin- $B_{12}$ therapy. The aetiological role of vitamin- $B_{12}$ deficiency is perhaps most clearly seen in Case 15 (Table III). We believe that this pigmentation is so typical as to be practically diagnostic of vitamin$B_{12}$ deficiency.

The frequent association with megaloblastic anaemia raises the question of whether folic-acid deficiency can cause a similar picture. However, we have not so far encountered it in cases of pure folic-acid deficiency unassociated with vitamin- $B_{12}$ deficiency. The partial response of Case 13 to large doses of folic acid was probably related to the concomitant rise in serumvitamin- $B_{12}$ levels which occurred during the period of administration of folic acid (Johnson et al., 1962).

Although the commonest cause of vitamin- $B_{12}$ deficiency in this series was a malabsorption syndrome, Cases 10, 14, and 16-21 show that the pigmentation can also arise from vitamin- $B_{12}$ deficiency of purely dietary origin.

Studies of adrenal function show a low resting level of 17-ketogenic steroids and a rather poor response to A.C.T.H. when compared with Western figures. However, the results are not significantly different from those obtained to date in a study in this laboratory of "normal" South Indians of similar economic status (Jacob et al., 1963), and adrenal hypofunction appears to play no part in the production of this pigmentation.

Personal communications in 1961 from X. J. Ankelesaria, of Delhi, M. J. Sandozi, of Hyderabad, and J. N. Pohowalla, of Indore, suggest that this type of pigmentation also occurs in patients in other parts of India, where it is also probably related to vitamin $B_{12}$ deficiency. Bisht and Singh (1962), from Pondicherry, describe pigmented bands on the nails of Indians as a "sign of malnutrition." The photograph they publish shows pigmentation on the dorsum of the fingers as well as in the nails. Unfortunately they do not publish any haematological findings, but we believe that the pigmentation described by them is of a similar kind to that described here.

Although a patchy pigmentation of the skin has been recorded in pernicious anaemia (Castle and Minot, 1936 ; Strauss and Brokaw, 1951; Wintrobe, 1961), it is of interest that this peculiar type of pigmentation of the fingers and toes does not appear to have been reported in Causasians with vitamin- $B_{12}$ deficiency. It would seem probable that the biochemical reactions which are responsible for the production of melanin in pigmented skins must be influenced by the presence of vitamin- $B_{12}$ deficiency, but the role of vitamin $B_{: 2}$ in pigment metabolism has yet to be elucidated.

Other types of skin pigmentation may be seen in cases of sprue and malabsorption syndrome, but these do not seem to bear any direct relationship to vitamin- $B_{12}$ deficiency.

\section{Summary}

Fifteen South Indian adults and six infants with hyperpigmentation of the skin, most pronounced on the dorsal aspect of the fingers and toes, have been studied.

This hyperpigmentation is associated with vitamin$B_{12}$ deficiency, and is so characteristic as to be practically diagnostic of this condition.

The mechanism by which the vitamin- $\mathrm{B}_{12}$ deficiency produces the hyperpigmentation is not yet known. It is not related to adrenal dysfunction.
We wish to thank Dr. J. K. G. Webb for permitting us to study Cases 16 to 21 and for allowing us to include them in this series. We also wish to thank Dr. K. I. Vytilingam, Dr. P. Koshy, and Dr. F. M. Narielwalla for kindly referring cases ; Mr. S. P. Swaminathan, Mr. D. Gnanasundaram, and Mr. R. Jacob for technical help; and Mr. S. D. Sigamoni for the photographs.

ADDENDUM.-Since submitting the above paper for publication we have studied a further five cases with typical hyperpigmentation, in which both serum vitamin $B_{12}$ and serum folate activities were measured. The serum-folate activity was measured microbiologically, using Lactobacillus casei as the test organism.

\begin{tabular}{|c|c|c|c|c|}
\hline & Patient & & $\underset{(\mu \mu \mathrm{g} . / \mathrm{ml} .)}{\text { Serum Vit. }} \mathrm{B}_{12}$ & $\begin{array}{c}\text { Serum Folate } \\
(\mu \mu \mathrm{g} \cdot \mathrm{ml} .)\end{array}$ \\
\hline $\begin{array}{l}\mathrm{Mu} \\
\mathrm{Th} \\
\mathrm{Su} \\
\mathrm{Pa} \\
\mathrm{An}\end{array}$ & $\begin{array}{ll}\ldots & \ldots \\
\cdots & \ldots \\
\cdots & \ldots \\
. & \ldots\end{array}$ & $\begin{array}{l}\ldots \\
\ldots \\
\cdots \\
\cdots\end{array}$ & $\begin{array}{l}70 \\
43 \\
49 \\
44 \\
40\end{array}$ & $\begin{array}{r}5 \cdot 0 \\
2 \cdot 4 \\
7 \cdot 1 \\
25 \cdot 0 \\
16 \cdot 7\end{array}$ \\
\hline
\end{tabular}

It will be seen that three out of five cases had serumfolate levels above $7 \mu \mu \mathrm{g} . / \mathrm{ml}$, , confirming our impression that the pigmentation is related more to vitamin$\mathrm{B}_{12}$ deficiency than to folic-acid deficiency.

REFERENCES

Bahr, P. H. (1915). A report on researches on sprue in Ceylon.

Cambridge Univ. Press.

Bisht, D. B., and Singh, S. S. (1962). Lancet, 1, 507

Castle, W. B., and Minot, G. R. (1936). Pathological Physiology and Clinical Description of the Anaemias, edited by $\mathrm{H}$. A Christian, p. 244. Oxford Univ. Press.

Dacie, J. V. (1956). Practical Haematology, 2nd ed. Churchill, London.

Gibson, G., and Norymberski, J. K. (1954). Ann. rheum. Dis., 13, 59.

Jacob, R., Johnson, S., Ignatius, M., and Baker, S. J. (1963). To be published.

Jadhav, M., Webb, J. K. G., Vaishnava, S., and Baker, S. J. (1962). Lancet, 2, 903.

Johnson, S., Swaminathan, S. P., and Baker, S. J. (1962). J. clin. Path., 15, 274.

Ross, G. I. M., Hutner, S. M., and Bach, M. J. (1957). Vitamin $B_{12}$ and Intrinsic Factor, 1, Europäisches Symposion. Ferdinand Enke, Stuttgart.

Strauss, M. B., and Brokaw, R. (1951). New Engl. J. Med., 245. 798.

Wintrobe, M. M. (1961). Clinical Haematology, 5th ed., p. 473. Lea and Febiger, Philadelphia.

A new edition of B.S.1805 brings up to date the information contained in Notes on Methods of Screening Hospital Patients. This standard was first published in 1951 as the result of an investigation, carried out at the request of the Hospital Equipment Standards Advisory Committee, into the methods of screening used in various types of hospital. The Advisory Committee recommended the preparation of a British Standard for mobile screens, which was published in 1952 as B.S.1895. As far as other methods of screening were concerned-such as curtains or partitions-it was considered impossible to specify the most satisfactory kind since a wide variety was called for to suit the needs of different types of hospital. However, B.S.1805 gave advice on the advantages and disadvantages of the various types of screening available, and these notes, with their numerous illustrations, have proved helpful both in equipping new hospitals and adapting old ones. The new edition omits all reference to curtain rings, which are considered obsolete, and recommends the use of nylon wheels or gliders to reduce noise. Account has also been taken of the growing practice of transforming large wards of the "Nightingale" pattern by dividing them into smaller sections for up to six beds. Copies of B.S.1805 may be obtained from the B.S.I. Sales Branch, 2 Park Street, London W.1. (Price 4s. 6d. each, postage extra to non-subscribers.) 